\title{
Endemic Goiter - an update
}

\author{
Demetrios A. Koutras
}

Endocrine Unit, "Evgenidion Hospital", Athens University School of Medicine, 11528 Athens, Greece

\section{INTRODUCTION}

"Goiter" means thyroid enlargement, and "endemic" means frequent in a certain locality. The problem is from what volume and up a thyroid is considered to be large enough as to be classified as goiter and also from what prevalence and up an area is considered to be endemic. It is obvious that by playing with these definitions one may increase or decrease the prevalence of goiter perceived in an area and also change the characterization of an area from endemic to nonendemic or vice versa.

In the past, goiter was defined as a thyroid gland enlarged 4 to 5 times above normal, and more practically as a thyroid with lobes greater than the terminal phalanges of the thumb of the person examined ${ }^{1}$. Nowadays, the size of the thyroid gland is assessed by ultrasonography. By these means, Delange et $\mathrm{al}^{2}$ suggested variable upper limits for children and addescents at different ages e.g. an upper limit of $16 \mathrm{ml}$ for boys and girls aged 15years and $5 \mathrm{ml}$ for boys and girl aged 6years. These data have been obtained in areas with a urinary iodine excretion of at least 100 $\mu \mathrm{g} / \mathrm{l}$. These limits have also been recommended by WHO and ICCIDD ${ }^{3}$. For adults an upper limit of 25

Key words: Cancer thyroid, Cretinism, Goiter endemic, Goitrogens, Hyperthyroidism, Hypothyroidism, Iodine deficiency, Selenium.

Address correspondence and requests for reprints to: Prof. D.A. Koutras, Vas. Sofias 35, Athens, 10675 Greece Phone No: ++3-0107211.319, Fax No: ++3-0107246.003 E-mail:damakoutras@hotmail.com

Received 27-02-02, Revised 08-03-02, Accepted 19-04-02 $\mathrm{ml}$ for men and $18 \mathrm{ml}$ for women has been suggested with smaller values for children ${ }^{2-4}$. There is now a tendency to further decrease the upper normal limits. This would result in many persons with a small subclinical and non-palpable enlargement being classified as goitrous. The author doubts whether these subclinical enlargements should raise a concern.

Regarding the word endemic, this has been defined as a prevalence rate of more than $10 \%$. There is now a tendency to decrease this figure from $10 \%$ to $5 \%$. Therefore, more areas will be classified as having a problem of endemic goiter.

To conclude, the tendency to decrease the upper normal limit of the thyroid volume together with the altered definition of endemicity from $10 \%$ to $5 \%$ will result in classifying several regions as endemic, whereas, in fact, the problem is not truly significant.

In this paper the problem of endemic goiter is reviewed with special emphasis on the studies of endemic goiter in Greece performed by our own team.

\section{ETIOLOGY AND PATHOGENESIS}

The main cause of endemic goiter is the lack of iodine $^{6}$. There is no renal homeostatic mechanism to keep the plasma inorganic iodine (PII) within the normal range ${ }^{7,8}$. Thus, the PII fluctuates more or less directly with the iodine intake. The lower the iodine content in the diet, the lower the PII.

Adaptation to the iodine intake is achieved by a thyroidal mechanism. When the PII falls, the Thyroid Clearance of iodide (Th. Cl.) increases, i.e. the thyroid clears a higher volume of plasma from its iodide 
content. In this way, the absolute amount of iodide taken up by the thyroid (AIU = Absolute Iodine Uptake) stays to a certain degree constant. That is, in the equation

$$
A I U=\text { Th. } C l \cdot x P I I
$$

the Th. Cl. changes inversely to the PII so as to keep the AIU normal. If the PII drops, owing to iodinedeficiency, Th. Cl. increases and this increase in function is associated with an increase in the volume of the thyroid gland ${ }^{7,8}$. The thyroid normally needs about $2.5 \mu \mathrm{g} / \mathrm{hr}$ for thyroid hormone synthesis. When the PII level is $2.5 \mu \mathrm{g} / \mathrm{l}$, the thyroid has to clear one 1 of plasma to obtain these $2.5 \mu \mathrm{g}$ of iodine. If the PII is $1 \mu \mathrm{g} /$ 1 , the thyroid must clear 2.51 of plasma. If the PII falls to below $0.8 \mu \mathrm{g} / \mathrm{l}$ and the thyroid has to clear more than three 1 of plasma per hour, thyroid enlargement (goiter) may develop.

The situation is complicated by other factors. Exogenous goitrogens $\mathrm{s}^{9-18}$, such as cassava ${ }^{9,16}$, may lead to goiter, either by potentiating a mild iodine deficiency or autonomously. Vegetables from the genus Brassica may release thiocyanate, a well-known goitrogen ${ }^{11-13,15-18}$. Several other goitrogens have been described in various plants as well as in the drinking water. Iodine in large concentrations is in itself a goitrogen. "Iodide goiter" has been described in Japan in a coastal area where the inhabitants consumed large quantities of sea-plants with a high iodine content ${ }^{19}$, and recently in China due to a high iodine concentration in the drinking water ${ }^{20}$. The authors of the above studies suggest that iodine should not exceed $300 \mu \mathrm{g} / \mathrm{l}$ in the drinking water or $800 \mu \mathrm{g} / \mathrm{l}$ in the urine of the inhabitants.

In iodine-deficient populations not everyone is goitrous $^{5,21}$. This phenomenon may be due to genetic factors. We have shown that there is a higher concordance rate for goiter in monozygotic than in dizygotic twins $^{22}$. Such a difference in the thyroid size may be due to differences in the efficiency for utilising iodine, for instance iodide binding ${ }^{23}$.

The adaptation of man to iodine deficiency does not involve only an increase in the thyroidal iodide clearance. In iodine deficient areas, the ratio of $\mathrm{T}_{3}$ to $\mathrm{T}_{4}$ increases not only in the thyroid but also in the plasma ${ }^{24} . \mathrm{T}_{3}$ contains less iodine than $\mathrm{T}_{4}$ and is also metabolically more potent, hence this represents an additional mechanism to compensate for iodine deficiency. Which is the optimum iodine intake? Considering iodine kinetics, Wayne et $\mathrm{al}^{8}$ concluded that al- though some persons could adapt with $70 \mu \mathrm{g}$ iodine/ day, others would need $120 \mu \mathrm{g}$, depending on the renal iodide clearance, while $160 \mu \mathrm{g}$ iodine/day constitute a safe level. We have found ${ }^{25}$ that serum TSH is lower when the urinary iodine is $150-200 \mu \mathrm{g} / \mathrm{g} \mathrm{Cr}$, or equivalent to an intake of about $200 \mu \mathrm{g} /$ day if the fecal excretion is also taken into account.

Most authors and authorities broadly agree with these figures and the general conclusion may be that although euthyroidism may be maintained with as little as $50 \mu \mathrm{g} /$ day, usually at the expense of goiter formation the optimum intake is 150 or $200 \mu \mathrm{g} / \mathrm{day}$. Pregnant women have higher requirements since in pregnancy the renal clearance of iodide increases to about twice the normal rate, thus reducing the level of $\mathrm{PII}^{26,27}$.

Another trace element interplaying with iodine and influencing thyroid function is selenium ${ }^{28}$. Type I iodo-thyronine deiodinase, which plays a crucial role in the action of thyroid hormones, contains seleni$u^{29}$. Currently the synergistic effect of selenium deficiency in the development of endemic cretinism is well recognized ${ }^{30-32}$. Surprisingly perhaps, selenium supplements decrease the levels of anti-TPO autoantibodies in autoimmune thyroiditis ${ }^{33}$.

\section{EPIDEMIOLOGY}

Since iodine deficiency is the main cause of endemic goiter, the epidemiology of endemic goiter largely depends on the iodine intake of the population.

Primitive societies depend on locally produced food. The iodine content of this food in turn, depends on the iodine content of the soil and the water. Thus, if the soil and the water do not contain enough iodine, nor does the locally produced food, endemic iodine deficiency goiter appears. A notable exception must be made for populations consuming sea-food, which is rich in iodine. Iodine-poor soils are usually found in mountainous areas remote from the sea, with considerable soil erosion, mainly due to intense previous glaciation ${ }^{34}$.

In ancient times goiter was very common and was depicted in many ancient statues, including those of the Buddha, the famous Queen Cleopatra of Egypt, etc. As recently as some decades ago endemic goiter was very prevalent ${ }^{35,36}$, affecting for instance, the northwest and south-east USA, several areas of Central and 
South America and notably the Andes and southern Brazil, several central European countries and notably the Alps and the Pindos mountain range in Greece, several areas of Turkey, several areas of Africa, of which Congo has been extensively studied by Belgian teams, many areas in Asia, including the Himalayas and South-East Asia, New Guinea, New Zealand, etc. In these areas a variable proportion of the population was affected by endemic goiter. In general, the prevalence of goiter (by palpation) peaked during puberty, and then decreased in the males ${ }^{37}$.

In addition to exogenous goitrogens and genetic factors, the socio-economic conditions play a role in goiter formation. Najjar and Woodruff ${ }^{38}$ reported that rural populations and lower socio-economic classes are especially affected. Our findings ${ }^{39}$ and those of Brahmblatt et $\mathrm{a}^{40}$ that endemic goiter is associated with evidence of generalised malnutrition support the findings of Najjar and Woodruff ${ }^{38}$. It should be noted that the more expensive animal sources of food contain more iodine than the cheaper vegetable food items ${ }^{41}$. Hence, poverty must be regarded as a cause of endemic goiter, as discussed later in the chapter on silent iodine prophylaxis.

The epidemiology of endemic goiter has now radically changed thanks to the supply of iodine, either deliberately as described below or through the socalled silent iodine prophylaxis. In Greece, iodine intake is now generally normal ${ }^{42}$ and several recent unpublished studies have confirmed the virtual eradication of endemic goiter from Greece. In most villages, the only goitrous children were those who had recently emigrated from less developed countries. Today, the predominant type of non-toxic goiter in Greece is autoimmune thyroiditis ${ }^{43}$. Tsatsoulis et $\mathrm{al}^{44}$ also found increased autoimmunity and urinary iodine excretion in a previous iodine-deficient area of northwestern Greece. A similar improvement in iodine intake has been reported from Brazil ${ }^{45}$, the Netherlands ${ }^{46}$ and Bosnia-Herzegovina ${ }^{47}$. The entire western hemisphere now nears iodine sufficiency ${ }^{48}$.

Nevertheless, the problem still does exist ${ }^{49-52}$. Several endemic areas persist, especially in rural areas and in developing countries. Since the situation varies from year to year, in order to draw up a map of the global incidence of endemic goiter, a worldwide collaboration of health authorities and research workers is essential. According to WHO, UNICEF and IC-
CIDD $^{51}$, in 1998 over one third of the total world population lived in iodine deficient areas. According to Delange ${ }^{49-50}$, in 1990 out of 5438 million people round the world, 1572 were at risk of iodine deficiency, and 655 millions ( $12 \%$ of the total world population) were actually goitrous, $2 \%$ were cretins and even more had some degree of mental retardation. It is not clear how many of these goitrous persons actually had a clinically significant goiter rather than a small thyroid enlargement.

In any case, it is the author's impression that endemic iodine deficiency goiter, although far from being eradicated, is at least not so frequent or serious as in the past in the developed countries and is also gradually becoming a less serious problem in the developing countries. This, of course should not diminish our efforts to completely eradicate iodine deficiency worldwide.

\section{HEALTH CONSEQUENCES OF ENDEMIC GOITER}

The first and most obvious consequence of iodine deficiency goiter is the goiter itself. If large enough, it constitutes more than a cosmetic problem and may also cause pressure symptoms.

Furthermore, iodine deficiency may be accompanied by hypothyroidism. In severe iodine deficiency, the thyroid gland cannot compensate by the means of the mechanisms previously described. The formation of thyroid hormones is reduced and TSH levels rise. A tragic result of this may be endemic cretinism ${ }^{53}$, which is more likely to occur if selenium deficiency is superimposed upon iodine deficiency, as previously discussed. In severely iodine-deficient areas, the thyroid hormones produced by pregnant women are not enough to ensure the normal development of the fetal brain. Later in gestation, the hormones, produced by the fetus are also not sufficient. The result is endemic cretinism, accompanied by neurological symptoms owing to the lack of thyroid hormones during fetal life and postnatally, if hypothyroidism persists after birth. Cretinism does not follow the rule "whole or none". In addition to overt cretinism, there are other milder degrees of mental retardation and hearing impairment ${ }^{5,55}$. A more extensive review of endemic cretinism is outside the scope of this paper other than the mention that endemic cretinism has been noted mainly in the Himalayas, the Andes and Congo and elsewhere, and was also present in central Europe sev- 
eral centuries ago.

As stated above, iodine requirements are increased during pregnancy. In iodine deficient areas with endemic goiter, pregnancy is accompanied by increased abortions, neonatal deaths and defective progeny, with various degrees of mental retardation extending even to overt cretinism $^{56}$.

Another problem of endemic goiter is hyperthyroidism. In long-standing goiters autonomous nodules develop ${ }^{57}$. This may lead to hyperthyroidism, especially if the iodine intake is increased, as discussed later in the context of iodine prophylaxis. This also happens spontaneously. Barker and Phillips ${ }^{58}$ found in 12 British cities that the incidence of hyperthyroidism was greater in areas where iodine-deficiency had been present in the past, and this high incidence was due to toxic nodular goiter ${ }^{59}$. This is also in agreement with more recent papers ${ }^{60,61}$, according to which in iodine deficient Denmark there were more cases of toxic nodular goiter in the elderly, whereas in iodine-rich Iceland there were more cases of Graves' disease in the young and of hypothyroidism in the elderly. The higher prevalence of Graves' disease and hypothyroidism in Iceland must be attributed to the increased prevalence of thyroid autoimmunity due to a high iodine intake.

Finally, carcinogenesis must be discussed. An increase in thyroid cancers in the endemic areas has been reported in the past ${ }^{62-64}$. Now, however, the contrary has been found through fine sections of the glands: in iodine-replete areas, not only the proportion of papillary carcinomas but also the total prevalence of thyroid cancers increases ${ }^{65}$. The practical conclusion may be stated as follows: in iodine deficiency, although the total number of thyroid carcinomas may be lower, the mortality from thyroid cancer is increased owing to the increased frequency of aggressive follicular and anaplastic thyroid carcinomas. On the other hand, in iodine-replete areas, although the total frequency of thyroid cancers is increased, mortality is decreased since the overwhelming majority of thyroid tumours in iodine sufficient areas are subclinical papillary micro-carcinomas.

\section{THE TREATMENT OF ENDEMIC GOITER}

The obvious advice, i.e. to supply iodine in iodinedeficient persons, may be miraculous for prevention but is only moderately effective in established goiters. According to the author's experience, only diffuse goiters in young persons have a chance of shrinking, usually only to a limited extent. In long-standing nodular goiters, iodine is contraindicated since it may precipitate hyperthyroidism.

In these cases thyroxine administration is more effective, especially in diffuse goiters. If autonomous nodules are present, exogenous thyroxine is added to the hormones secreted by the nodules and a hyperthyroid condition state may result.

Surgery is usually required for large goiters with pressure symptoms and/or autonomous nodules. This procedure requires an experienced surgeon and a well organized hospital, and none of these is readily available in the developing countries where endemic goiter is usually present.

Instead of surgery, many now give ${ }^{131} \mathrm{I}$ in large amounts $^{66}$, but again modern facilities are essential. The injection of ethanol in prominent nodules is simpler and may be used without elaborate equipment.

\section{THE PREVENTION OF ENDEMIC GOITER}

Since treatment of endemic goiter is neither easy nor very effective, prevention must be our main concern. The theoretical basis is very simple: for iodine deficiency supply iodine, and when goitrogens are present eliminate them. This is more easily said than done. Goitrogens are especially difficult to avoid. They may be contained in the staple foods on which a population survives, for instance cassava (manioc), millet, etc. It is difficult to advise their avoidance if there are not healthier alternatives available. It may also be difficult to modify the water supply in order to avoid water-borne goitrogens.

Since iodine deficiency is the main cause of endemic goiter, its eradication is the basis for prevention of endemic goiter ${ }^{49-51}$. Iodine may be supplied in various ways. Iodine tablets or other forms of iodine to be taken on a daily or weekly basis are not very practical. The main ways to administer iodine to a population are: a) iodized salt, b) iodized oil, c) water iodination, d) others.

Iodized salt (10-100 parts of potassium iodide or iodate per million) is perhaps the most practical measure for developed countries with a modern salt industry ${ }^{67}$. 
Injection of iodized oil supplies enough iodine for one or more years ${ }^{68-70}$. Iodized oil can be taken also per os. Water iodination can be used in communities with a central water supply. Furthermore, adding iodine to bread or to anything else widely consumed may be effective. All these procedures are so well known that we need not discuss them further.

In addition to this deliberate supply of iodine, there is also the so-called "silent iodine prophylaxis", i.e. a spontaneous increase in iodine intake due to various factors. These factors, also previously discussed, include a) economic growth, allowing people to buy more expensive but also iodine-rich food, b) better communications, with the result that previously isolated areas can now also consume food produced elsewhere, and c) the industrialization of food production, which results in an increased iodine content of food, as reviewed by Koutras et $\mathrm{al}^{34}$.

Although in Greece iodized salt was introduced following the author's efforts, silent iodine prophylaxis is probably the main reason for the elimination of iodine deficiency ${ }^{42}$. Nowadays, the predominant form of non-toxic goiter in Greece is autoimmune thyroiditis ${ }^{43}$. Iodine deficiency goiter has been virtually eradicated. In some previously endemic areas which we have recently re-examined, the iodine intake, as judged by the urinary iodine excretion, has been found adequate.

In Athens, the average urinary iodine was in 1964 $45 \pm 5 \mu \mathrm{g} / \mathrm{d}^{71}$, increased to $94 \mu \mathrm{g} / \mathrm{gCr}$ in $1980^{72}$, to $208 \pm 156 \mu \mathrm{g} / \mathrm{gCr}$ in $1992^{42}$ and was in $1999229.9 \pm 21.2$ $\mu \mathrm{g} / \mathrm{gCr}$ in goitrous persons with autoimmune goiter compared to $204.7 \pm 21.6$ in persons with non-autoimmune goiter ${ }^{43}$. In many villages known for their endemic goiter, we have observed the following situation: children were more or less non-goitrous, thanks to better iodine nutrition, while their parents in many cases had an obvious and significant goiter as a result of a previous iodine deficiency.

The results of iodine prophylaxis must be monitored. Clinical examination of the thyroid is valuable but since the results appear later (established goiters usually do not regress), it is better to monitor the iodine excretion in the population ${ }^{73}$.

\section{SIDE EFFECTS OF IODINE}

Iodine, whether given for prophylaxis or for treatment, has several untoward effects ${ }^{73}$. Hyperthyroidism is not only the most important of these but perhaps also the one best studied, described as long as 180 years ago by Coindet $^{74}$. Iodine-induced hyperthyroidism is usually associated with autonomous nodular goiters, as shown in Tasmania ${ }^{75-77}$, in Britain by Barker et $\mathrm{al}^{58,59}$, in Zaire ${ }^{78}$ and elsewhere. This subject has been reviewed by Stanbury et $\mathrm{al}^{79}$.

Iodine-induced autoimmunity is also a problem, though less important. Our group reported the emergence of antithyroid auto-antibodies after administration of iodized oil i.m..$^{80,81}$ or KI orally ${ }^{82}$. Our results have been challenged by some authors, but fully confirmed by Kahaly et al $^{83,84}$ who were the first to find lymphocytic infiltration after iodine administration. An increased prevalence of thyroid autoimmune disorders in countries with a high iodine intake has also been detected. Harach and Williams ${ }^{65}$ found in Argentina, in surgical specimens from females, lymphocytic infiltration in $8 \%$ before and $25 \%$ after iodine prophylaxis. Furthermore, iodine-induced autoimmunity is well known in animals. This subject has been reviewed by several authors, including ourselves ${ }^{81}$. In any case, iodine-induced autoimmunity is not such a problem as to deter the authorities from iodine supplementation.

Thyroid cancer was also mentioned previously. It seems that after iodine supplementation the total prevalence of thyroid cancer increases ${ }^{65}$, but since this concerns an increase in subclinical papillary thyroid cancers and is accompanied by a decrease in lethal anaplastic and follicular cancers, the over-all mortality from thyroid cancer decreases.

All in all, it seems that iodine-induced hyperthyroidism is the only serious consequence of iodine administration ${ }^{73,79}$. This, however, is only a transient phenomenon: once iodine deficiency has been eradicated there are practically no more autonomous thyroid nodules, and therefore no iodine-induced hyperthyroidism. Iodine- induced autoimmunity may result in more cases of Graves' and Hashimoto's diseases, but these entities are easily controlled.

Conclusion: if iodine deficiency is present, do eradicate it! 


\section{REFERENCES}

1. Querido A, Delange J, Dunn T, Fierro-Benitez R, Ibbertson HK, Koutras DA, Perinetti H 1974 Definitions of endemic goiter and cretinism classification of goiter size and severity of endemics, and survey techniques. In: Dunn TJ, Medeiros-Neto GA (eds) Endemic Goiter and Cretinism: Continuing Threats to World Health. PAHO, WHO Scient Publications No: 29, Washington DC, USA, pp, 267272.

2. Delange F, Benker G, and Caron P, 1997 Thyroid volume and urinary iodine in European schoolchildren: standardization of values for assessment of iodine deficiency. Eur J Endocrinol 130: 180-187.

3. WHO-ICCIDD, 1997 Recommended normative values for thyroid volume in children aged 6-15 years. Bull WHO 75: 95-99.

4. Zimmermann MB, Molinari L, Spechl M, Widninger-Toth J, Podoba J, Hess S, Delange F, 2001 Updated provisional WHO-ICCIDD reference values for sonographic thyroid volume in iodine-replete school-age children. IDD Newsletter 17: 12.

5. Koutras DA, 1971 Non-toxic goiter: endemic. In: The Thyroid. A Fundamental and Clinical Text. 3d ed., eds SC Werner and SH Ingbar, Harper and Row, New YorkEvanston-San Francisco-London 11: 409-423.

6. Stanbury JB, Brownell GL, Riggs DS, Perinetti H, Del Castillo EB, I Itoiz J, 1954 Endemic Goiter. The Adaptation of Man to Iodine Deficiency. Harvard University Press. Cambridge, Mass, USA.

7. Riggs DS, 1952 Quantitative aspects of iodine metabolism in man-Pharmacol Rev 4: 284-306.

8. Wayne EJ, Koutras DA, Alexander WD, 1964 Clinical Aspects of Iodine Metabolism. Blackwell Scientific Publications, Oxford, England.

9. Delange F, Thilly C, Ermans AM, 1968 Iodine deficiency, a permissive condition in the development of endemic goiter. J Clin Endocrinol Metab 28: 114-116.

10. Gaitan E, Wahner HW, Correa P, Bernal R, Jubiz W, Gaitan JE, Llanos G, 1968 Endemic goiter in the Cauca Valley: I. Results and limitations of twelve years of iodine prophylaxis. J Clin Endocrinol Metab 28: 1730-1740.

11. Delange F, Ermans AM, 1971 Role of a dietary goitrogen in the etiology of endemic goiter in Idjwi Island. Am J Nutr 24: 1354-1359.

12. Ermans AM, Bourdoux P, 1989 Antithyroid sulfurated compounds. In: Gaitan E, ed. Environmental Goitrogenesis. Boca Raton, Fl: CRC Press: USA.

13. Langer P, Greer MA, 1977 Antithyroid Substances and Naturally Occurring Goitrogens, Basel: Karger.

14. Podoba J, Langer P, 1964 Naturally Occurring Goitrogens and Thyroid Function. Bratislava: Publishing House of the Slovak Academy of Sciences.

15. Gaitan E, 1989 Environmental Goitrogenesis. Boca Raton, Fl: CRC Press.

16. Delange F, Iteke FB, Ermans AM, 1982 Nutritional Factors Involved in the Goitrogenic Action of Cassava. Ottawa: International Development Research Centre.
17. Gmelin R, Virtanen AI, 1960 The enzymic formation of thiocyanate $(\mathrm{SCN})$ from a precursor(s) in Brassica species. Acta Chem Scand 14: 507-511.

18. Bourdoux P, Delange F, Gerard M, Mafuta M, Hanson A, Ermans AM, 1978 Evidence that cassava ingestion increases thiocyanate formation: a possible etiologic factor in endemic goiter. J Clin Endocrinol Metab 46: 613-621.

19. Suzuki H, Higushi T, Sawa K, Khtaki S, Koniuchi Y, 1965 Endemic coast goiter in Hokkaido, Japan. Acta Endocrinol 87: 1020-1022.

20. Zhao J, Wang P, Shang L, Sullivan KM, Van der Haar F, Maberly G, 2000 Endemic goiter associated with high iodine intake. M J Public Health 90: 1633-1635.

21. Koutras DA 1974 Variations in incidence of goiter within iodine-deficient populations. In: Dunn JT, MedeirosNeto GA (eds) Endemic Goiter and Cretinism Continuing Threats to World Health. PAHO, WHO Scient Publications No: 292, Washington DC, USA; pp, 45-101.

22. Malamos B, Koutras DA, Kostamis P, Rigopoulos GA, Zerefos NC, Yataganas XA, 1967 Endemic goitre in Greece: a study of 379 twin pairs. J Med Genet 4: 16-18.

23. Koutras DA, Souvatzoglou A, Pandos PG, Papachristou DN, Piperingos GD, Sfontouris J, 1978 Iodide organification defect in iodine deficiency endemic goiter. J Clin Endocrinol Metab 47: 610-614.

24. Vagenakis AG, Koutras DA, Burger A, Malamos B, Ingbar SH, Braverman LE, 1973 Studies of serum triiodothyronine, thyroxine and thyrotropin concentrations in endemic goiter in Greece. J Clin Endocrinol Metab 37: 485488.

25. Moulopoulos DS, Koutras DA, Mantzos J, Souvatzoglou A, Piperingos GD, Karaiskos KS, Makriyannis D, Sfontouris J, Moulopoulos SD, 1988 The relation of serum T4 and TSH with the urinary iodine excretion. J Endocrinol Invest 11: 437-439.

26. Aboul-Khair SA, Crooks J, Turnbull AC, Hytten FE, 1964 The physiological changes in thyroid function during pregnancy. Clin Sci 27: 195-207.

27. Koutras DA, Pharmakiotis AD, Koliopoulos N, Tsoukalos J, Souvatzoglou A, Sfontouris J, 1978 The plasma inorganic iodine and the pituitary thyroid axis in pregnancy. J Endocrinol Invest I: 227-231.

28. Corvilain B, Contempre B, Longombe RO, Geyem P, Gervy-Decostar C, Lamy F, Vanderpas JB, Dumont JE, 1993 Selenium and the thyroid: how the relationship was established. Am J Clin Nutr 57 (supl 2) 244-248.

29. Berry MJ, Banu L, Larsen PR, 1991 Type I iodothyronine deiodinase is a seleno-cysteine-containing enzyme. Nature 349: 438-440.

30. Vanderpas JB, Contempre B, Duale NL, Goossens W, Bebe N, Thorpe R, Ntambue K. Dumont J, Thilly CH, Diplock AT, 1990 Iodine and selenium deficiency associated with cretinism in northern Zaire. Am J Clin Nutr 52: 1087-1093.

31. Vanderpas JB, Contempre B, Duale NL, Deckx H, Bebe N, Longombe AO, Thilly CH, Diplock AT, Dumont JE, 1993 Selenium deficiency mitigates hypothyroxinemia in iodine-deficient subjects. Am J Clin Nutr 57: 271-275. 
32. Contempre B, Dumont JE, Denef JF, Many MC, 1995 Effects of selenium deficiency on thyroid necrosis, fibrosis and proliferation: a possible role in myxoedematous cretinism. Eur J Endocrinol 133: 99-109.

33. Gasnier B, Dietrich J, Angstwurm M, Gartner R, 2001 Selenium substitution in patients with autoimmune thyroiditis decreases anti-TPO autoantibodies concentration. J Encrinol Invest 74, suppl to No 6, 69.

34. Koutras DA, Matovinovic J, Vought RL, 1980 The ecology of iodine. In: Stanbury JB Hetzel BS (eds) Endemic Goiter and Endemic Cretinism. Iodine Nutrition in Health and Disease. John Wiley and Sons, New York Chichester - Brisbane - Toronto; pp, 185-195.

35. Kelly FC, Snedden WW 1960 Prevalence and geographical distribution of endemic goitre. In: Clements FW, Endemic Goitre, WHO, Geneva; pp, 27-253.

36. Stanbury JB and Hetzel BS eds, 1980 Endemic Goiter and Endemic Cretinism. Iodine Nutrition in Health and Disease. John Wiley and Sons, New York- Chichester - Brisbane - Toronto.

37. Malamos B, Koutras DA, Kostamis P, Kralios AC, Rigopoulos G, Zerefos N, 1966 Endemic goiter in Greece: Epidemiologic and genetic studies. J Clin Endocrinol Metab 26: 688-695.

38. Najjar SS, Woodruff CW, 1963 Some observations of goiter in Lebanon. Amer J Clin Nutr 13: 46-51.

39. Koutras DA, Christakis G, Trichopoulos D, DakouVoutetaki A, Kyriakopoulos V, Fontanares P, Livadas DP, Gatsios D, Malamos B, 1973 Endemic goiter in Greece: nutritional status, growth and skeletal development of goitrous and non-goitrous populations. Amer J Clin Nutr 26: $1360-1368$.

40. Brahmblatt SR, Brahmblatt RM, Boyages SC, 2001 Impact of protein energy malnutrition on thyroid size in an iodine deficient population of Gujarat (India). Eur J Endocrinol 145: 11-17.

41. Koutras DA, Papapetrou PD, Yataganas X, Malamos B, 1970 Dietary sources of iodine in areas with and without iodine deficiency goiter. Amer J Clin Nutr 23: 870-874.

42. Koutras DA, Piperingos G, Mantzos J, Boukis M, Karaiskos KS, Hadjiioannou S 1993 Iodine nutrition and iodine deficiency in Greece: Signs of improvement. In: Delange F, Dunn JT, Glinoer D (eds) Iodine Deficiency in Europe: A Continuing Concern. Plenum Press. New York and London; pp, 421-426.

43. Doufas AG, Mastorakos G, Chatziioannou S, TseleniBalafouta S, Piperingos G, Boukis MA, Mantzos E, Caraiskos CS, Mantzos J, Alevizaki M, Koutras DA, 1999 The predominant form of non-toxic goiter in Greece is now autoimmune thyroiditis. Eur J Endocrinol 140: 505511.

44. Tsatsoulis A, Johnson EO, Andricula M, Kalogera C, Svarna E, Spyrou P, Seferiadis K, Tsolas O, 1999 Thyroid autoimmunity is associated with higher urinary iodine concentrations in an iodine-deficient area of Northwestern Greece. Thyroid 9: 279-283.

45. Rossi AC, Tomimori E, Camargo R, and Medeiros-Neto G, 2001 Searching for iodine deficiency disorders in schoolchildren from Brazil: The Thyromobil Project. Thyroid 11: 661-663.

46. Wiersinga WM, Podoba J, Srbecky M, van Vessem M, van Beeren HC, Platvoet-Ter Schiphorst MC, 2001 A survey of iodine intake and thyroid volume in Dutch schoolchildren: reference values in an iodine-sufficient area and the effect of puberty. Eur J Endocrinol 144: 595-603.

47. Tahirovic H, Toromanovic A, Hadzibegic N, Stimljanin D, Konjevic R, Budimic Z, Cengic H, Roncevic Z, Denjo E, Huskic J, Hadzimujic I, Moro D, Ivankovic A, Dodik N, Hasanbegovic S, 2001 Assessment of the current status of iodine prophylaxis in Bosnia and Herzegovina Federation. J Pediatr Endocrinol Metab 14: 1139-1144.

48. Anonymous, 2001 The Western Hemisphere nears iodine sufficiency. IDD Newletter 17/1: 1-9.

49. Delange F 2000 Iodine deficiency. In Braverman LE and Utiger RD (eds) The Thyroid - A Fundamental and Clinical Text, 8th ed, Lippincott, Philadelphia, USA; pp, 795316.

50. Delange F, de Benoist B, Pretell E, Dunn JT, 2001 Iodine deficiency in the world: where do we stand at the turn of the century? Thyroid 11: 437-447.

51. WHO, UNICEF, ICCIDD, 1999 Progress towards the elimination of iodine Deficiency Disorders (IDD). WHO publ, Geneva, pp, 1-33.

52. Dunn JT, 2001 Correcting iodine deficiency is more than just spreading around a lot of iodine. Thyroid 11: 363364.

53. Pharoah P, Delange F, Fierro-Benitez R, Stanbury JB 1980 Cretinism. In: Stanbury JB and Hetzel BS (eds) Endemic Goiter and Endemic Cretinism. Iodine Nutritition in Health and Disease. John Wiley and Sons, New York- Chichester-Brisbane-Toronto; pp, 395-421.

54. Dodge PR, Palkes H, Fierro Ramirez I, 1969: Effect on intelligence of iodine in oil administered to young Andean children. A preliminary report In: Stanbury J B ed Endemic Goiter PAHO. Washington DC, USA; pp, 378380.

55. Fierro Benitez R, Ramirez I, Estrella E, Stanbury JB 1974 The role of iodine in intellectual development in an area of endemic goiter. In: Dunn JT and Medeiros Neto GP (eds) Endemic Goiter and Cretinism: Continuing Threats to World Health. PAHO Scient Publ 292, Washington DC, USA; pp, 135-142.

56. Dunn JT, Delange F, 2001 Damaged reproduction: the most important consequence of iodine deficiency. J Clin Endocrinol Metab 86: 2360-2363.

57. Studer H, Hunziger NR, Ruchti E, 1978 Morphologic and functional substrate of thyrotoxicosis caused by nodular goiter. Am J Med 65: 227-233.

58. Barker DJP, Phillips DIW, 1984 Current incidence of thyrotoxicosis and past prevalence of goitre in 12 British towns: Lancet 2: 567-570.

59. Phillips DIW, Barker DJP, Smith BR, 1985 The geographical distribution of thyrotoxicosis in England according to the presence or absence of TSH-receptor antibodies. Clin Endocr 23: 283-289.

60. Laurberg P, Pedersen KM, Vestergaard H, Sigurdsson G, 
1991 High incidence of multinodular toxic goiter in the elderly population in a low iodine intake area vs. high incidence of Graves' disease in the young in a high iodine intake area; comparative surveys of thyrotoxicosis epidemiology in East-Jutland Denmark and Iceland. J Intern Med 229: 415-420.

61. Laurberg P, Pedersen KM, Hireidanrson A, Sigfusson N, Iversen E, Knudsen PR, 1998 Iodine intake and the pattern of thyroid disorders: a comparative epidemiological study of thyroid abnormalities in the elderly in Iceland and in Jutland, Denmark. J Clin Endocrinol Metab 83: 765-769.

62. Wegelin C, 1928 Malignant disease of the thyroid gland and its relation to goiter in man and animals. Cancer Rev 3: 297.

63. Wahner HW, Cuello C, Correa P, Uribe L, Gaitan E, 1966 Thyroid carcinoma in an endemic goiter area. Cali. Am J Med 40: 58.

64. Belfiore A, La Rosa GL, Padova G, Sava L, Ippolito O, Vigneri R, 1987 The frequency of cold thyroid nodules and thyroid maligancies in patients from an iodine-deficient area. Cancer 60: 3096-3101.

65. Harach HR, Williams ED, 1995 Thyroid cancer and thyroiditis in the goitrous regions of Salta, Argentina, before and after iodine prophylaxis. Clin Endocr 43: 701707.

66. Nygaard B, Faber J, Veje A, Hansen JEM, 1997 Thyroid volume and function after 131I treatment of diffuse nontoxic goitre. Clin Endocrinol 46: 493-496.

67. Hunnikin C, Wood FO 1980 Iodination of salt. In: Stanbury JB and Hetzel BS (eds) Endemic Goiter and Endemic Cretinism. Iodine Nutrition in Health and Disease. John Wiley and sons, New York-Chichester-BrisbaneToronto; pp, 497-512.

68. Buttfield IH, Hetzel BS, 1967 Endemic goitre in Eastern New Guinea with special reference to the use of iodized oil in prophylaxis and treatment. Bull WHO 36: 243-262.

69. Buttfield IH, Hetzel BS, Odell WD, 1968 Effect of iodized oil on serum TSH determined by immunoassay in endemic goiter subjects. J Clin Endocrinol Metab 28: 1664-1666.

70. Hetzel BS, Thilly CH, Fierro-Benitez R, Pretell EA, Buttfield IH, Stanbury JB 1980 Iodized oil in the prevention of endemic goiter and cretinism. In: Stanbury JB and Hetzel BS(eds) Endemic Goiter and Endemic Cretinism. Iodine Nutrition in Health and Disease. John Wiley and Sons, New York - Chichester - Brisbane - Toronto; pp, 513-532.

71. Malamos B, Miras K, Koutras DA, Kostamis P, Binopoulos D, Mantzos J, Levis G, Rigopoulos G, Zerefos N, Tassopoulos CN, 1966 Endemic goiter in Greece: metabolic studies. J Clin Endocrinol Metab 26: 696-704.
72. Koutras DA, Katsouyanni K, Livadas DP, Piperingos GD, Tzonou A, Trichopoulos D, 1982 An epidemiologic survey of thyroid enlargement among schoolchildren in a non-endemic area. Endokrinologie 79: 349-354.

73. Koutras DA, 1996 Control of efficiency and results, and adverse effects of excess iodine administration on thyroid functions. Ann Endocrinol (Paris) 57: 463-469.

74. Coindet JF, 1821 Nouvelles recherches sur les effets de l' iode et sur les pricautions $\hat{v}$ suivre dans le traitement du goitre par ce nouveau rem $\theta$ de. Bibliotheque Universelle des Sciences et Belles-Lettres Arts 36: 140.

75. Connolly RJ, Vidor GI, Stuart JC, 1970 Increase in thyrotoxicosis in endemic goitre area after iodation of bread. Lancet 1: 500-505.

76. Vidor GI, Stewart JC, Wall JR, Wangel A, Hetzel BS, 1973 Pathogenesis of iodine induced thyrotoxicosis: studies in Northern Tasmania. J Clin Endocrinol Metab 37: 901-909.

77. Adams DD, Kennedy TH, Stewart JC, Utiger RD, Vidor GI, 1975 Hyperthyroidism in Tasmania following iodide supplementation: Measurements of thyroid-stimulating autoantibodies and thyrotropin. J Clin Endocrinol Metab 41: 221-228.

78. Delange F, de Benoist B, Alnwick D, 1999 Risks of iodine-induced hyperthyroidism following correction of iodine deficiency by iodized salt. Thyroid 9: 545-556.

79. Stanbury JB, Ermans AM, Bourdoux P, Todd C, Oken E, Tonglet R, Vidor G, Braverman LE, Medeiros-Neto, 1998 Iodine-induced hyperthyroidism: Occurrence and epidemiology. Thyroid 8: 83-100.

80. Boukis MA, Koutras DA, Souvatzoglou A, Evangelopoulou A, Vrontakis M, and Moulopoulos SD, 1983 Thyroid hormone and immunological studies in endemic goiter. $\mathbf{J}$ Clin Endocrinol and Metab 57: 859-862.

81. Papanastasiou L, Alevizaki M, Piperingos G, Mantzos A, Tseleni-Balafouta S, Koutras DA, 2000 The effect of iodine administration on the develoment of thyroid autoimmunity in patients with nontoxic goiter. Thyroid 10: 493497.

82. Koutras DA, Piperingos GD, Pallas D, Katsouyanni K, Karaiskos KS, Marafelia P, Makriyannis D, Kitsopanides J, Sfontouris J, Mantzos J, 1990 Clinical, laboratory and immunologic effects of the treatment of endemic goiter with T4, T3 and K1. Thyroidology 2: 81-88.

83. Kahaly G, Dienes HP, Beyer J, Hommel G, 1997 Randomized, double-blind, placebo-controlled trial of low dose iodide in endemic goiter. J Clin Endocrinol Metab 82: 4049-4053.

84. Kahaly GJ, Dienes HP, Beyer J, Hommel G, 1998 Iodide induces thyroid autoimmunity in patients with endemic goitre: A randomized, double-blind, placebo-controlled trial. Eur J Endocrinol 139: 290-297. 